beg to leave to the unbiassed consideration of my professional brethren, and of the public, whose comfort and lives are concerned in the proper administration of this important enactment:

I am, Sir, yours sincerely, GEORgE W. BALFour, M.D.

Shandwick-place, Edinburgh, March, 1860.

THE

\section{CASE OF ALFRED GODFREY, AN ALLEGED LUNATIC.}

To the Editor of The Lancet.

SIR,-Had my letter of the 12th instant, or a fair comment on it, appeared in your columns, I should not again have troubled you on the subject, becanse it would have shown that it was not written for the purpose of vindicating the conduct of, or to justify the course adopted by, my father and myself (who, by the bye, am not the brother alluded to in your article of the 3rd instant, and who, although acquiescing in the course adopted-deeming it to be for the benefit of my brother, never took any active part therein), there being nothing either to vindicate or justify.

You erroneously state that the real justification consists in the belief of the father and brother that Alfred Godfrey was actually insane. I clearly prove that such was not the case, but that it was the conclusion arrived at, and communicated to the members of the family, by various medical gentlemen (whose names I will, if desired, supply you with), and that it ultimately became impossible to treat him otherwise than as being so.

You say you are pleased to hear that an apartment was provided for and weekly allowance made to him on his discharge from Colney Hatch; but you do not say, as appears from my former letter-from the fact of the strangeness of his actions, and his not being able to content himself for any length of time, and his requiring attention and to be supplied with food at all hours of the day and night-how futile our doing so appears to be. Your remark, that it is very probable he requires medical treatment, I am at a loss to understand, though I do not doubt he himself imagines such to be the case.

It is unnecessary for me to recall attention to many portions of your article of the 3rd instant, because you have not ventured to reiterate them, and therefore their falsity may be con. cluded to be established by my reply thereto.

I can but regret that a journal conducted, as yours is professedly avowed to be, on liberal principles, should endeavour to add to the misery of a family already sufficiently great by the knowledge that one member thereof should be in the state my unfortunate brother is; and I shall, on their part, feel much obliged to you, or any of your readers, if they will kindly point out what is the proper course to pursue in the case of a young man declared by many to be insane, yet discharged from a public institution for the treatment of diseases of that nature as not so; whose friends are not in a position, but who he imagines are bound to supply him with every luxury he requires; who is constantly in the habit of disturbing persons in the middle of the night, labouring under the idea that he is dying; and although taking many more meals per day than any reasonable human being would, yet imagines he is always sinking from want.

In concluding, I feel bound again to repeat that without blaming the relations you cannot, with any degree of justice, say that Alfred Godfrey has been subjected to much cruel and unnecessary suffering; the force of which remark I am unable to comprehend, because the steps taken after a considerable time and with the utmost reluctance was the only course ultimately open for them to pursue.

I am, Sir, your most obedient servant, Southampton Buildings, Chancery-lane, ED. GodFrex.
Narch 19th, 1860.

\section{To the Editor of The LANCET.}

Sir, - In your leading article of the 3rd instant you thought proper to insert a long letter, making use of my name and that of my unfortunate son, A. L. Godfrey, and wishing to show me up to the world as an unnatural parent,- the large manufacturing jeweller of Clerkenwell, - first sending him to a madhouse, and then allowing him to come out without shelter or food to wauder about the streets, - which is a gross falsehood. You cannot plead ignorance at taking the one-sided question, 332 as I had occasion to write you before, wherein I stated that I conld produce certificates from gentlemen standing high in the profession. All I have to say, in my humble opinion, and the opinion of many others, that a more unjustifiable discharge could not have taken place by the doctor of Colney Hatch institution, after a short period of less than six weeks, without a trial to cure, and stating there was nothing the matter with him, either in mind or body.--I remain, Sir, yours \&c., St. John-street-road, March, 1860 .

G. Lazarus.

* We are quite willing to allow Mr. G. Lazarus and Ed. ward Godfrey to state their own case. Their letters, like the former one from which we extracted the points most favourable to them, indicate that unhappy influence upon the temper and judgment which the belief in the insanity of a relative is apt to exert. Mr. E. Godfrey, in adverting to our suggestion that his unfortunate brother probably requires medical treat. ment, says he is "at a loss to understand" how this can be. Yet he declares his conviction that his brother is insane. He must, therefore, be at a loss to understand that insanity is a disease eminently ealling for medical treatment. We repeat our doubts whether the handcuffs, the visit to Bethlehem, the confinement in the Clerkenwell Lunatic Ward, or in Colney Hatch, have cured Alfred Godfrey of his alleged lunacy. If not cured, he still requires treatment, not of the latter kind, which certainly has done no good, but medical treatment.

And if the treatment referred to have done him no good, then it was " unnecessary," and, if unnecessary, "cruel." If Mr. Edward Godfrey repudiates the idea that his conduct and that of his family does not require justification on the ground of their belief that Alfred Godfrey was insane, we do not understand how they would wish to justify it. Messrs. Lazarus and $\mathrm{E}$. Godfrey appeal to the testimony of gentlemen standing high in the profession in confirmation of Alfred Godfrey's in. sanity. They do not mention the names of these gentlemen. They omit the fact that other medical gentlemen do not concur in that opinion. They singularly misconstrue the significant circumstance that Alfred Godfrey has been discharged from Colney Hatch after six weeks' detention, there being " nothing the matter with him, either in mind or body."

The letters printed above will induce the candid reader to suspect that we have dealt rather too tenderly than otherwise with the writers. -ED. L.

\section{F O R E I G N W I N E S. \\ To the Editor of The LANCET.}

SrR,-Perhaps you can spare me a small portion of your valuable space to make a few remarks on the subject of French wines, now promised as such a boon to Englishmen.

I would first suggest that these wines are all, with very rare exceptions, made up for the English market: if so made up at present, how much more so when there is a far greater demand for them at home!

Living near to the wine growing provinces of both France and Spain, we are inundated with wines of inferior quality, from the price of a real $\left(2 \frac{1}{4} d.\right)$ per bottle and upwards; and I have, during my residence here, particularly noticed their effect on the English constitution in the persons of my patients, com. prising several hundred navvies. "The 'rioccho,' or red wine of the country, is a fruity wine, with a dry after-taste, un palatable at first, but the taste soon becomes habituated. It contains little or no nourishment; it causes diarrbœa at first, and subsequently a tendency to dyspepsia." I find that the flesh of persons drinking these wines is very tardy in repara. tion, and that the constitution cannot so easily shake off an acute disease as in otber circumstances. As these are the only drinks within the reach of my patients (saving " aguardiente," which is worse than poison), I consider myself competent to form an opinion on the point.

These wines, if admitted at a cheaper rate into England, will form no boon to the working classes, for even supposing them to be placed within the range of their pockets, they will not be found to contain the pabulum requisite to sustain the strength of the operative. The only class, it strikes me, they will benefit are the people who now drink them, and are fully able to pay the full price for them.-I am, Sir, yours truly, Bilbro, Spain, March, 1860. J. INGLebY MACKENZIE, M.R.C.S. 